\title{
Effects of soil fertility and compaction on root dynamics in a perennial ryegrass-white clover pasture
}

\author{
M.B. DODD and A.D. MACKAY \\ AgResearch, Grasslands Research Centre, Private Bag 11008, Palmerston North 4442 \\ mike.dodd@agresearch.co.nz
}

\begin{abstract}
Pasture root mass and production were measured in two experiments in the Manawatu region. The first examined the effects of nitrogen $(\mathrm{N})$ inputs and soil phosphorus (P) status over one year (2008/9) and the second examined the interacting effects of soil $\mathrm{P}$ status and artificial soil compaction over one year (2011/12). Root mass was measured by soil core sampling and root production was measured by an in-growth core technique, to $120 \mathrm{~mm}$ depth. Over most of the two periods studied there were no significant differences in root mass or production between treatments. However, higher $\mathrm{N}+\mathrm{P}$ fertility resulted in $20 \%$ lower root mass but $32 \%$ higher root production during September and November 2008. In 2011/12, soil compaction reduced root production by approximately $22 \%$ yearround. Increased soil P fertility did not compensate for this effect. Fertility effects on root growth seem more influenced by $\mathrm{N}$ than $\mathrm{P}$ in this system.
\end{abstract}

Keywords: nitrogen, phosphorus, root production, soil compaction

\section{Introduction}

The dynamics of root growth are an important consideration for every ecosystem service that we derive from pasture systems, whether it is primary productivity to supply forage for animal production, efficient nutrient use to mitigate losses to sensitive waterways, or accumulation of soil carbon to mitigate greenhouse gas emissions. Yet there remains insufficient data on many aspects of root growth in New Zealand pastures, particularly the responses of the relevant pasture species to environment and management factors.

Documented variation in pasture root mass and production in response to management and environmental drivers was presented in a previous NZGA paper (Dodd et al. 2011), which noted that most of the variation in root mass under grazed grass-clover pastures occurred in the top $100 \mathrm{~mm}$ of soil. The studies examined included the effects of soil fertility (Dodd \& Mackay 2011; Jacques 1943), grazing intensity (Matthew et al. 1991; Nie et al. 1997), species (Crush et al. 2005; Evans 1978; McKenzie et al. 1990), and aspect (Barker et al. 1988). Additional, previously unpublished, data also presented in Dodd et al. (2011) included the effects of phosphorus (P) and nitrogen $(\mathrm{N})$ fertility and species. In general, higher soil fertility status appeared to lead to decreased root mass but greater root production; lower grazing residuals led to decreased root mass; and species differences were highly idiosyncratic, no doubt interacting with site factors.

This paper reports on two factorial experiments designed to measure the effect of $\mathrm{N}$ fertiliser inputs, $\mathrm{P}$ fertility and soil compaction on root mass and root production under a Manawatu perennial ryegrass (Lolium perenne) and white clover (Trifolium repens) pasture. One experiment has been reported in detail elsewhere (Dodd \& Mackay 2011) but a comparison with the subsequent experiment is instructive from a methodological point of view, as well as affording the opportunity to separate $\mathrm{P}$ and $\mathrm{N}$ effects. The objective was to determine to what degree root characteristics responded to these management manipulations in order to infer the likely production and environmental outcomes for high-producing pastures.

\section{Methods}

\section{Experimental location}

Both field experiments were in fenced exclosures at the same location, a paddock formerly grazed by dairy cows. The site is located $3 \mathrm{~km}$ southeast of Colyton in the Manawatu District (NZTM 1827900E, 5541190N, Alt. $120 \mathrm{~m}$ ). The soil type is a Marton silt loam, a Luvisol (Hewitt 1992). The pasture was sown in 2004 with a mixture of perennial ryegrass $\left(25 \mathrm{~kg} \mathrm{ha}^{-1}\right.$, cvs. 'Bronsyn' and 'Meridian'), and white clover ( $3 \mathrm{~kg} \mathrm{ha}^{-1}$, cvs. 'Aran', 'Grasslands Sustain' and 'Grasslands Kopu'). The measurements reported here were part of a larger multi-year study examining the soil fertility requirements of modern pasture cultivars (Mackay et al. 2010).

\section{Experiment I: Effect of $\mathbf{P}$ and $\mathbf{N}$}

The first experiment compared root mass and production using consecutive measurements over one year (September 2008-September 2009) on small plots $(4 \mathrm{~m} \times 1.5 \mathrm{~m})$. The two soil fertility treatments used were no added $\mathrm{P}$ or $\mathrm{N}$, and a higher fertility treatment with $\mathrm{P}$ applied annually as triple superphosphate (14 g 
$\left.\mathrm{P} \mathrm{m}^{-2} \mathrm{yr}^{-1}\right)$ and $\mathrm{N}$ applied after each pasture harvest as urea $\left(40 \mathrm{~g} \mathrm{~N} \mathrm{~m}^{-2} \mathrm{yr}^{-1}\right)$. Each treatment had four replicate plots. Soil Olsen P levels in the two treatments were 20-24 and 40-45 $\mathrm{\mu g} \mathrm{ml}^{-1}$ (Mackay et al. 2010) and thus the treatments are designated $\mathrm{P} 25$ and $\mathrm{P} 45+\mathrm{N}$ respectively. Basal nutrients $(\mathrm{S}, \mathrm{K}, \mathrm{Ca}, \mathrm{Mg}, \mathrm{Cu}, \mathrm{Zn}$, Mo, B) were applied four times per year at appropriate rates (Mackay et al. 2010). Annual rainfall at the site was $940 \mathrm{~mm}$ and the plots were irrigated daily between December-March to maintain soil moisture between 25 and $45 \% \mathrm{v} / \mathrm{v}$.

Above-ground herbage accumulation was measured with a rising plate meter, using the manufacturer's calibration for dairy pastures (Farm Tracker, Farmworks Ltd, Feilding). Measurements were made prior to and following mowing at 4-8 week intervals depending on growth rates. Harvested herbage was not returned to the plots.

Root mass was measured by extracting nine soil cores of $25 \mathrm{~mm}$ diameter sampled to two depths (0$80 \mathrm{~mm}$ and $80-160 \mathrm{~mm}$ ) on each measurement date. Samples were taken in September 2008, October 2008, November 2008, January 2009, March 2009, April 2009, June 2009, July 2009 and September 2009 from different locations in the plot. The samples for each date/plot/treatment/depth combination were measured for root dry matter by hand washing to extract visibly intact roots (a mixture of live and senescing material). The root tissue was dried at $65^{\circ}$ for 24 hours and weighed to determine dry mass.

Root production was measured by an in-growth core technique (Allard et al. 2005). On each plot three cavities ( $38 \mathrm{~mm}$ diameter, $250 \mathrm{~mm}$ length) were created by soil coring at a $45^{\circ}$ angle. The soil was removed and replaced by a PVC tube with $30 \mathrm{~mm}$ wide $\times 160 \mathrm{~mm}$ long windows cut out of the upper and lower surfaces

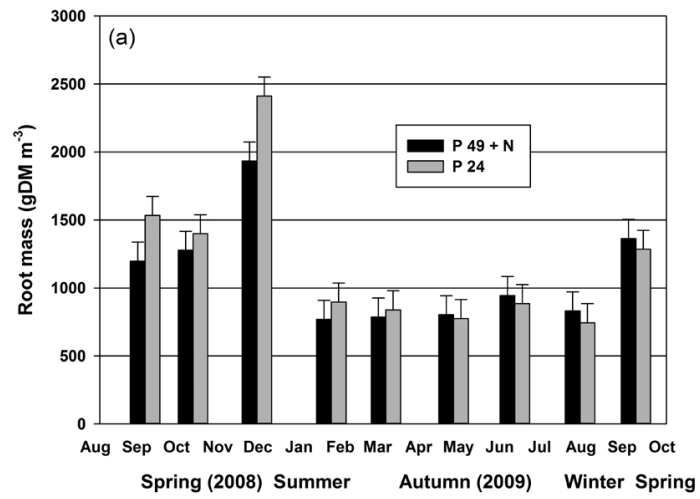

(a) to allow root penetration between the vertical depths of 0 and $120 \mathrm{~mm}$. At each of the nine sample dates noted previously for root mass, the tubes were re-filled with approximately $250 \mathrm{~g}$ of moist soil to a bulk density of $1050 \mathrm{~kg} \mathrm{~m}^{-3}$ equivalent and capped with a plastic top to prevent excessive drying. The soil used was an Egmont silt loam subsoil which had been sieved to pass $4 \mathrm{~mm}$ to remove roots and debris and stored moist for 6 months. At the end of each sample period (4-8 weeks depending on season) the refill soil was extracted and measured for root dry matter as described above.

Above-ground herbage accumulation, root mass and root production data were analysed with a repeated measures ANOVA using a randomised block model in Genstat v13.

\section{Experiment II: Effect of $\mathbf{P}$ and compaction}

The second experiment compared root mass and production over one year (February 2011-January 2012) on small plots $(5 \mathrm{~m} \times 2 \mathrm{~m})$. The treatments used involved a split-plot factorial design with two soil compaction (main plot) and two soil fertility (subplot) treatments. Each treatment combination had four replicate plots. The soil fertility treatments were a low fertility treatment with no added $\mathrm{P}$ and a high fertility treatment with $\mathrm{P}$ applied as triple superphosphate (36 $\left.\mathrm{kg} \mathrm{P} \mathrm{ha}{ }^{-1} \mathrm{y}^{-1}\right)$. Soil Olsen P levels in the two treatments were 13 and $60 \mu \mathrm{g} \mathrm{ml}^{-1}$ and thus the treatments are designated P13 and P60 respectively. Other basal nutrients were applied as for Experiment I. The soil compaction treatments were a no-compaction treatment and a high compaction treatment in which the plots were rolled on five occasions during the year, each with five passes, using a 4.5 tonne vibrating roller following herbage harvesting. Annual rainfall at the site was 1190 $\mathrm{mm}$ and the plots were not irrigated.

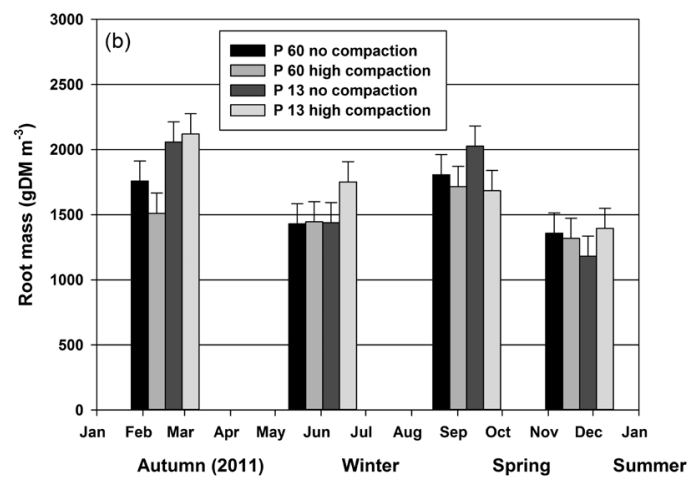

(b)

Figure 1. Root mass ( $\mathrm{g} \mathrm{DM} \mathrm{m} \mathrm{m}^{-3}$ between $0-120 \mathrm{~mm}$ depth) in two soil fertility experiments at Colyton (a) High $\mathrm{P}+\mathrm{N}$ vs Moderate $\mathrm{P}-\mathrm{N}$; and (b) $\mathrm{P}$ level $\times$ compaction level factorial. Bars represent SEM. 
Above-ground herbage accumulation was measured as for experiment I. The effect of compaction on soil was measured with a penetrometer, incorporating a $1 \mathrm{~kg}$ mass dropped from $1 \mathrm{~m}$ height. Ten measurements of penetration $(\mathrm{cm})$ were made on each main plot. Bulk density of the two compaction treatments was also measured in January 2011, using four steel rings (50 $\mathrm{mm}$ diameter, $50 \mathrm{~mm}$ deep) inserted into the topsoil, weighed moist and after drying at $105^{\circ} \mathrm{C}$ for 48 hours. The effect of the compaction treatment was to decrease mean penetrometer readings from 3.4 to $1.9 \mathrm{~cm}$ (SEM $=0.1 \mathrm{~cm})$ and increase bulk density from 970 to 1080 $\mathrm{kg} \mathrm{m}^{-2}\left(\mathrm{SEM}=30 \mathrm{~kg} \mathrm{~m}^{-2}\right)$.

Root mass and production measurements were made by sampling three cores per plot. In this case the samples measured for root mass were the soil extracted from cavities created for the in-growth cores (i.e. 38 $\mathrm{mm}$ diameter, $250 \mathrm{~mm}$ length, $45^{\circ}$ angle) prior to inserting the PVC tubes and the samples measured for root production were taken from the in-growth cores as in Experiment I, except that fresh cavities were used for each sample period. Soil was re-filled into the PVC tubes to the same bulk density as measured in the plots. The root mass measurements occurred on only four dates during the year and root production cores were extracted after a growth period relevant to seasonal herbage growth rates as follows: 1 . February $2011+8$ weeks; 2 . June $2011+10$ weeks; 3 . September $2011+6$ weeks; and 4 . November $2011+8$ weeks. Thus in contrast to Experiment I, the root production measurements were non-consecutive and taken from different locations in the plot for each sample period.

Statistical analysis of the data followed the same procedures as in Experiment I.

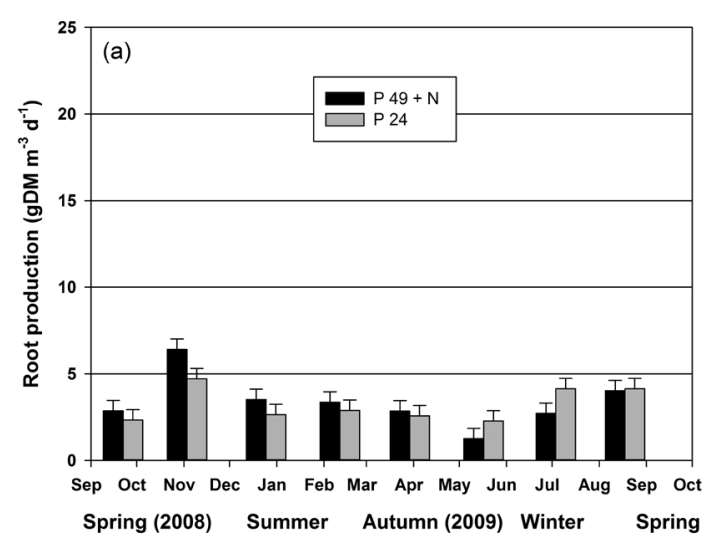

(a)

Figure 2 Root production ( $\mathrm{g} \mathrm{DM} \mathrm{m}^{-3}$ day $^{-1}$ between $0-120 \mathrm{~mm}$ depth) in two soil fertility experiments at Colyton (a) High $\mathrm{P}+\mathrm{N}$ vs Moderate P - N; and (b) P level $\times$ compaction level factorial. Bars represent SEM.

\section{Results}

In the first experiment, total aboveground net herbage accumulation between September 2008 and September 2009 was significantly greater for P49+N than P24 (23 200 vs $17800 \mathrm{~kg} \mathrm{DM} \mathrm{ha}^{-1} \mathrm{y}^{-1}$ respectively, $\mathrm{P}<0.05$ ). In the second experiment there was no significant difference in total aboveground net herbage accumulation between the soil $\mathrm{P}$ levels or compaction levels during the February 2011-January 2012 period (grand mean $10000 \mathrm{~kg} \mathrm{DM} \mathrm{ha}^{-1} \mathrm{yr}^{-1}, \mathrm{P}>0.05$ ).

In the first experiment root mass was significantly greater under the $\mathrm{P} 24$ treatment $(\mathrm{P}<0.05)$ only during September and November of 2008 (when the peak of root mass occurred) with the difference being approximately 20\% (Figure 1a). During the JanuaryJuly period, mass was consistently low and not different between fertility treatments. In the second experiment the seasonal pattern differed from that in the first experiment, with the lowest root mass in November $(\mathrm{P}<0.01$, Figure $1 \mathrm{~b})$. While there was some indication of greater root mass under the P13 treatment compared with the P60 treatment in February and September 2011, there was no significant main effect of the P levels. Additionally, there was no significant effect of compaction on root mass (Figure 1b).

In the first experiment, the seasonal pattern of root production measured in the in-growth cores was consistent with the root mass measurements in terms of increases in growth rate in the spring period (Figure 1a cf. Figure 2a). Root production in the second experiment appeared also to be consistent with this pattern, although the rates of production were approximately three to four times those measured in the first experiment at similar stages of the year (Figure $2 \mathrm{~b}$ cf. Fig 2a). In both experiments the date effect was significant $(\mathrm{P}<0.05)$. In the first experiment, root

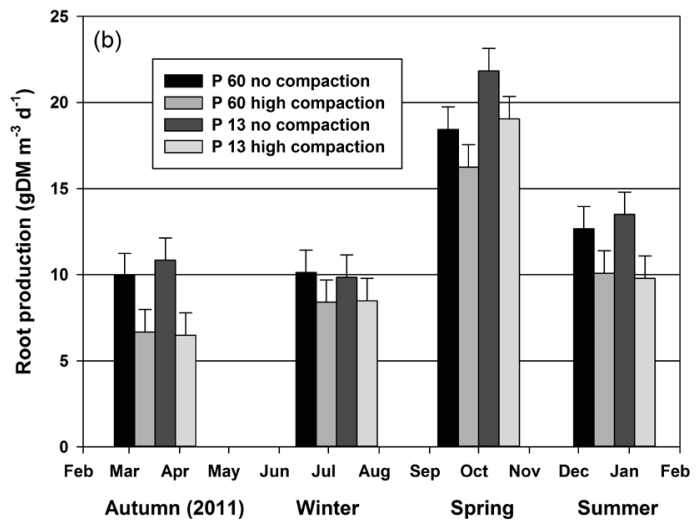

(b) 
production was significantly greater $(+32 \%)$ under the $\mathrm{P} 49+\mathrm{N}$ treatment in November 2008 and significantly less $(-35 \%)$ under the P49+N treatment in July 2009 (Fig 2a). There was no significant effect of P level on root production in the second experiment, but there was a significant main effect of compaction $(\mathrm{P}<0.01)$, reducing root production by $22 \%$ across all treatments and dates (Figure 2b). There was no significant interaction between $\mathrm{P}$ level and compaction level.

\section{Discussion}

There were substantial differences between the two experiments in terms of above- and below-ground biomass production. The much lower herbage accumulation in Experiment II was attributable to the lack of irrigation in this experiment, as the differences were largely seen in summer-autumn pasture plate readings. The large differences in root production between the two experiments can probably be attributed to differences in methods. In the first experiment the cavities were re-used for each consecutive growth period and the refilled soil was of non-local origin. Our previous methodological investigation of the effects of these factors suggested they would reduce root production by approximately three-fold (Dodd \& Mackay 2011). Use of fresh cavities at each sample date and local soil in the second experiment appears to confirm this assessment, as the measured root growth rates were three to four times greater than those observed in the first experiment.

Experiment I showed the expected effect of increased soil fertility on greater above-ground herbage accumulation, with only short-term differences in root mass and production observed in late winter and spring (Figures 1,2). Thus we might expect significant gains in forage supply without sacrificing below-ground attributes and associated benefits, such as root mass for soil stability and nutrient uptake, or root turnover for soil $\mathrm{C}$ sequestration. Experiments examining $\mathrm{C}$ allocation in perennial ryegrass-white clover based pastures have shown consistent decreases in proportional allocation to roots at higher P fertility (Saggar et al. 1997; Scott et al. 2012). However, they show contrasting effects on root mass (increases and decreases respectively) and in respect of root production Saggar et al. (1997) showed greater total $\mathrm{C}$ allocation to roots at higher fertility whereas Scott et al. (2012) showed no significant effect of fertility on root production. What does seem clear is a higher root turnover rate at higher fertility, which likely increases soil $\mathrm{C}$ input.

The effect of soil compaction on reducing root production was consistent year round (Figure 2), and has been observed elsewhere with perennial ryegrass (Sills \& Carrow 1983). The effects can be explained by the more challenging soil physical conditions for root growth (aeration, bulk density) inhibiting root extension rates (McMichael \& Quisenberry 1993; Shierlaw \& Alston 1984). The structure of the $\mathrm{P} \times$ compaction trial was designed to determine whether higher soil fertility status mitigated the effects of soil compaction, but this appears not to be the case, for either root or shoot growth (i.e. no significant interaction, Figure $2 b$ ), at least at the levels examined in this experiment. Decreased P uptake has been shown to be related to reduced root length in more highly compacted soils (Shierlaw \& Alston 1984) but there was no reduction in root mass observed here, under less severe bulk density conditions. Sills \& Carrow (1983) have also shown no compensatory effect of increased $\mathrm{N}$ input on reduction in perennial ryegrass growth due to compaction.

Comparing the results of the two experiments suggests that $\mathrm{N}$ has a greater influence than $\mathrm{P}$ on root mass and production under the experimental conditions. In Experiment I a greater root mass was observed at moderate $\mathrm{P}+\mathrm{N}$ fertility in spring, but there was no significant effect of a greater difference in $\mathrm{P}$ status in the second experiment. Likewise for root production in the first experiment a greater root growth rate was observed at high $\mathrm{P}+\mathrm{N}$ fertility in late spring, but there was no significant effect of a greater difference in $\mathrm{P}$ status in the second experiment. Greater root mass but lower turnover under lower soil fertility conditions has been observed elsewhere (van der Krift \& Berendse 2002) and has been hypothesised to be an adaptive trade-off driven by the constraints of tissue structure (Schlapfer \& Ryser 1996).

In addition, it is worth noting that the effects of the imposed differences in soil fertility and compaction led to differences in root mass and production of the order of $\pm 20-35 \%$, fairly consistent with environmentinduced effects in other New Zealand pasture studies (Dodd et al. 2011). This somewhat defines the potential for manipulating rooting patterns for production or environmental benefits. Genetic selection (Crush et al. 2006) and consideration of other species (Crush et al. 2005) may offer more potential in this regard.

\section{ACKNOWLEDGEMENTS}

Thanks to a number of AgResearch staff for assistance in the field, but especially Phil Budding for management of the experimental sites and Bridget Wise for root washing and drying. Colin MacMillan provided the site on his farm. We acknowledge funding from the Ministry of Business, Innovation and Employment for two programmes supporting this research, the Sustainable Land Use Research Initiative (SLURI, C02X0405) and the Pastoral Sustainable Forage Productivity Gains Programme (P21, C10X0604). 


\section{REFERENCES}

Allard, V.; Newton, P.C.D.; Lieffering, M.; Soussana, J.F.; Carran, R.A.; Matthew, C. 2005. Increased quantity and quality of coarse soil organic matter fraction at elevated $\mathrm{CO}_{2}$ in a grazed grassland are a consequence of enhanced root growth rate and turnover. Plant and Soil 276: 49-60.

Barker, D.J.; Zhang, D.M.; Mackay, A.D. 1988. Root distribution in a low fertility hill country sward grazed by sheep. New Zealand Journal of Experimental Agriculture 16: 73-76.

Crush, J.R.; Easton, H.S.; Waller, J.E. 2006. Genetic variation in perennial ryegrass for root profile characteristics. pp. 63-65. In: Advances in pasture plant breeding, 13th Australasian Plant Breeding Conference.

Crush, J.R.; Waller, J.E.; Care, D.A. 2005. Root distribution and nitrate interception in eleven temperate forage grasses. Grass and Forage Science 60: 385-392.

Dodd, M.; Mackay, A. 2011. Effects of contrasting soil fertility on root mass, root growth, root decomposition and soil carbon under a New Zealand perennial ryegrass/white clover pasture. Plant and Soil 349: 291-302.

Dodd, M.B.; Crush, J.R.; Mackay, A.D.; Barker, D.J. 2011. The "root" to more soil carbon under pastures. Proceedings of the New Zealand Grassland Association 73: 43-49.

Evans, P.S. 1978. Plant root distribution and water use patterns of some pasture and crop species. New Zealand Journal of Agricultural Research 21: 261-265.

Hewitt, A.E. 1992. New Zealand soil classification, DSIR Land Resources Scientific Report. Department of Scientific and Industrial Research, Lower Hutt.

Jacques, W.A. 1943. Root development in some common New Zealand pasture plants II. Perennial ryegrass (Lolium perenne), cocksfoot (Dactylis glomerata) and white clover (Trifolium repens). New Zealand Journal of Science and Technology 25: 91-117.

Mackay, A.D.; Gillingham, A.; Smith, C.; Budding, P.; Phillips, P.; Clarke-Hill, W.; Johnstone, P. 2010. Evaluation of the effects of grass species, irrigation, nitrogen fertiliser application and soil compaction on the response of modern dairy pastures to phosphorus fertiliser. Proceedings of the New Zealand Grassland Association 72: 153-158.

McKenzie, B.A.; Gyamtsho, P.; Lucas, R.J. 1990. Productivity and water use of lucerne and two lucerne-grass mixtures in Canterbury. Proceedings of the New Zealand Grassland Association 52: 35-39.

McMichael, B.L.; Quisenberry, J.E. 1993. The impact of the soil environment on the growth of root systems. Environmental and Experimental Botany 33: 53-61.

Matthew, C.; Xia, J.X.; Chu, A.C.P.; Mackay, A.D.; Hodgson, J. 1991. Relationship between root production and tiller appearance rates in perennial ryegrass (Lolium perenne L.). pp. 281-290. In: Plant root growth. Ed. Atkinson, D. British Ecological Society, Oxford.

Nie, Z.N.; Mackay, A.D.; Valentine, I.; Barker, D.J.; Hodgson, J. 1997. Influence of pastoral fallow on plant root growth and soil physical and chemical characteristics in a hill pasture. Plant and Soil 197: 201-208.

Saggar, S.; Hedley, C.; Mackay, A.D. 1997. Partitioning and translocation of photosynthetically fixed $14 \mathrm{C}$ in grazed hill pastures. Biology and Fertility of Soils 25: 152-158.

Schlapfer, B.; Ryser, P. 1996. Leaf and root turnover of three ecologically contrasting grass species in relation to their performance along a productivity gradient. Oikos 75: 398-406.

Scott, J.T.; Stewart, D.P.C.; Metherell, A.K. 2012. Alteration of pasture root carbon turnover in response to superphosphate and irrigation at Winchmore New Zealand. New Zealand Journal of Agricultural Research 55: 147-159.

Shierlaw, J.; Alston, A.M. 1984. Effect of soil compaction on root growth and uptake of phosphorus. Plant and Soil 77: 15-28.

Sills, M.J.; Carrow, R.N. 1983. Turfgrass growth, N use, and water use under soil compaction and $\mathrm{N}$ Fertilization1. Agronomy Journal 75: 488-492.

van der Krift, T.A.J.; Berendse, F. 2002. Root life spans of four grass species from habitats differing in nutrient availability. Functional Ecology 16: 198-203. 
